\title{
Employee Engagement Level: The Transform from Employee to Partner
}

\author{
Mohannad A.M. Abu Daqar ${ }^{1}$ \& Ahmad K.A. Smoudy ${ }^{2}$ \\ ${ }^{1}$ School of Management and Business Administration, Szent István University, Hungary \\ 2 Business Administration, Palestine \\ Correspondence: Mohannad A.M. Abu Daqar, School of Management and Business Administration, Szent István \\ University, 2100, Pater Karoly Utca 1, Gödöllö, Hungary. Tel: 36-70-540-9755. E-mail: \\ Mohannad.Abu.Daqar@phd.uni-szie.hu
}

Received: May 4, 2019

doi:10.5539/mas.v13n7p115
Accepted: June 20, 2019

Online Published: June 26, 2019

\begin{abstract}
Employee engagement recently has become a hot topic among the consulting firms and in the business press. The purpose of this study was to study and create further understanding of employee's engagement levels and how to stimulate it to the maximum as long as possible. A survey was completed by 55 employees working in private and governmental organization in Palestine from governmental service, manufacturing, technology, telecommunication, financing and other services like retailer, NGO cultural to generate the output of having a higher employees involvement in the governmental sector rather than the private one due to multiple factors, and having a higher employee engagement in the private sector than the public one due to the more financial and personal recognition they get there. The revealed results stressed that organizations need to recognize employees as assets and customers. Business activities are key parts of the employee lifestyle, so it has a direct impact at his reaction, so if the organization didn't control these reactions it will be the main drivers for his disengagement. Additionally, the employee engagement level is directly related to the efficiency of work and the overall company performance. The authors recommend adopting employee engagement transforming strategies by the public sector before the private one. Moreover, the study recommends that engagement transforming strategies must be employee-oriented not entity-oriented.
\end{abstract}

Keywords: employee engagement, industry competitiveness, employee perception, company classification

JEL Classifications: O10, O15, M12, M53

\section{Introduction}

Employees, one of the most important building terms into any business. No matter what type of company we are talking about or what sector the company operates in, no company can ignore one of its most valuable resources, the human one. This relies on many factors, mainly the sustainability as the company existence depends heavily on the human participation on a different structural level, whether it is in the first line or highest level, passing through the middle as well.

It is true that a satisfying business structure can lead to a happy employee and therefore to a high performing entity. But employees' behavior is continuously changing according to the human nature, in contrast with the business structure that is either fixed or changing much less frequent than the human fluctuations. Moreover, companies are continuously working to maintain the highest productivity. If it's not logically possible to keep changing the business structure or create one that fits all human changing needs, then employee continuous productivity is surely maintained by applying other long-term strategies and theories.

So, it is crucial at this point to study and create further understanding of employee's engagement levels and how to stimulate it to the maximum as long as possible. We should understand what truly motivates employees to maximize productivity and how to use it in the process of transferring them from employees "the basic engagement level" to partners "the highest".

Companies in specific fields like retail and manufacturing, for example, have been suffering from high employee's turnover for decades. This phenomenon reduces the efficiency of the company's overall performance because it increases the tasks of the recruitment departments and disperses the efforts of the employees working in the 
departments mentioned earlier. The authors believe that understanding employee's needs and perceptions can help in improving the efficiency of the human capital through working on their engagement level. Having a clear vision of what are the factors affecting the engagement level will give the HR departments in companies a specific guideline on how to engage their employees more in the indirect and direct decisions and efforts done by the company in different departments. Eventually, this will help in strengthening the company's overall performance which will affect the economic sectors in parallel.

\section{Definition of Key Terms}

- Employee Engagement: the emotional commitment that an employee has to the organization and its goals.

- Industry Competitiveness: the level of the direct head to head relation between companies within the same economic sector.

- Employee Perception: The future predictions set by employees regarding their career path inside the company's structure.

- Company Classification: A system for classifying companies based either on the size of the company and field of operation.

\section{Literature Review}

\subsection{Study Context}

Employees, or what the business like to call Human Power, is one of the most important pillars of the business existence and development in the future. Employees resemble business success and competitiveness within the market (Arthur, 1992). Attracting the human power with the needed talents might seem like a hard task, but maintain their full potentials as much as possible and engaging them into the business different current mission and future long-term vision is the hardest part. Investing in the human capital is the most beneficial investment, whether for businesses or even for nations, looking at this as an asset, it is highly required to benefit from this asset as long as possible by creating higher engagement and loyalty to the entity itself (Bailey, 1993).

In this study authors are classifying the factors that affect employee's engagement level within the Palestinian Companies, and whether such engagement and commitment influence the company competitive level within the industry. To achieve these study goals, authors have started with collecting secondary data from previous studies that have spotted the light on this issue in modern publications. The literature review will be the base to understand the origins of the employee engagement and clarify why it is an important topic to businesses all around the world and not only into the Palestinian local market. Afterward, primary data will be collected using a survey that was distributed among a selected sample which was sampled using SRS "simple random sampling". There are two different samples, the businesses as entities were studied using a questionnaire addressed to the human resource department. In parallel to focus groups that will be set with the business employees to collect data from both sides of the engagement level as a term to study in order to analyze the data and come up with an integrated quantitative and qualitative output that is leading to the research recommendations eventually.

Employee engagement is recognized by many international and locally operating businesses in recent years (Ramus, 2001). This increasing importance is a result of the increasing talent acquisitions acts and the belief that employees should be treated as a reversed-customer who needs continuous attention and stimulus motivating as they are with no doubt an important stakeholder that is effected from the inside of the company and reflects it on the outside public (Ramus,2001).

\subsection{Employee Engagement Level definition}

Employee engagement has no fixed definition that is agreed on upon all scholars. Some scholars define employee engagement "the harnessing of organization members' selves to their work roles, in engagement, people employ and express themselves physically, cognitively, and emotionally during their performances" (Kahn, 1990). This definition works in various pillars that are related to the part of the employee work experience. The cognitive pillar is related to the employee believes about the organization, its working conditions, and the management. The emotional pillar is driven by how positive or negative the employees feel regarding each of these three factors (organization, management, and working conditions). The third and last pillar, which is the physical, is about the physical energy exercised by individuals in order to accomplish the required tasks within their roles. In other words, engagement means to be physically and psychologically present when performing an organizational role (Kahn, 1990).

In addition to Kahn's three-pillar definition, engagement has been defined as "the emotional and intellectual commitment to the organization" (Baumruk, 2004) or "the amount of discretionary effort exhibited by employees 
in their job" (Frank, 2004). However, there is always the simplest definition that you can always find for any field, which is "passion for work" as defined by (Truss et al., 2006) this simple definition goes I parallel with Kahn definition that relies on the three pillars nut I simpler stimulus. As the passion for work will not be possible if there is no positive work environment with a healthy relationship with the organization leaders which will lead to physically perform well.

The existence of different definitions for any term can cause a problem as it wouldn't be possible to determine the drivers and deep analysis of the case researched. However, in the case of employee engagement, it is clear that there are different definitions that each covers the concept from a different perspective. In some modern researches, employee engagement definition has been developed to overcome the definition compatibility and the result was to mistakenly define it under new terms such as (Organization commitment and organization citizenship) (Ferguson, 2007). In this research, we will adopt Kahn's definition as it integrates most of the other definitions on a way or another, and it analyses the relationship between employee engagement level and company's internal stakeholders that upon Kahn's affect the performance of the employee eventually.

\subsection{What are the Levels of Employee Engagement?}

Employee engagement has several levels that allocate the employee level of commitment to the company overall. Engagement levels vary depending on the definition vision, as we have adopted Kahns employee engagement definition earlier. Levels of engagement in this research will be classified based on employee participation on the comprehensive performance committed by employees at each level of engagement and its effect on the company.

Based on Don Rheem there are three levels of employee engagement that could be found at mostly every organization (Rheem, 2017) as follows:

\subsubsection{Highly Engaged Employees}

These employees are the alpha players of the company who transform the workplace into a cell of productivity, innovation, and fun. When these employees work along with co-workers who are positive, reliable, and predictable, they will be capable to accomplish more than they would if doing it alone. These alpha players in companies could motivate others, coworkers, and less engaged employees to improve their engagement level on a certain project or within the same period that they work together.

\subsubsection{Engaged Employees}

These employees who make up to $20-25 \%$ of most companies (Rheem, 2017). Represent the performance backbone for the company as they focused on their works and to deliver their roles on time with a positive outlook. They are working hard and usually believe in the mission of the company. Many of the engaged employees get inspired by highly engaged employees and usually create their own self-motivation.

\subsubsection{Actively Disengaged}

These employees who are present and absent at the same time, who attend to work every day and has specific roles that they don't tend to improve it any point. This type of employees makes up to $50 \%$ of most businesses. They are clock-punchers who are doing the work but with no intentions to perform their full potential. This can be due to bad conditions of management. However, these disengaged employees try to resist the feeling of affiliation to the entity as much as possible and look at the company only as a check payer every month (Rheem, 2017).

These different levels of engagement are present at more than $70 \%$ of enterprises around the globe (Rheem, 2017) and always changing. Which means that highly engaged employees can shift down to become engaged employees and another way up, even highly disengaged employees can become highly engaged employees if managed well. That's why companies tend not to dismiss highly disengaged employees because it is always possible for research development departments that every employee performs their full potentials at some point of their career life cycle (Markos, 2010). 


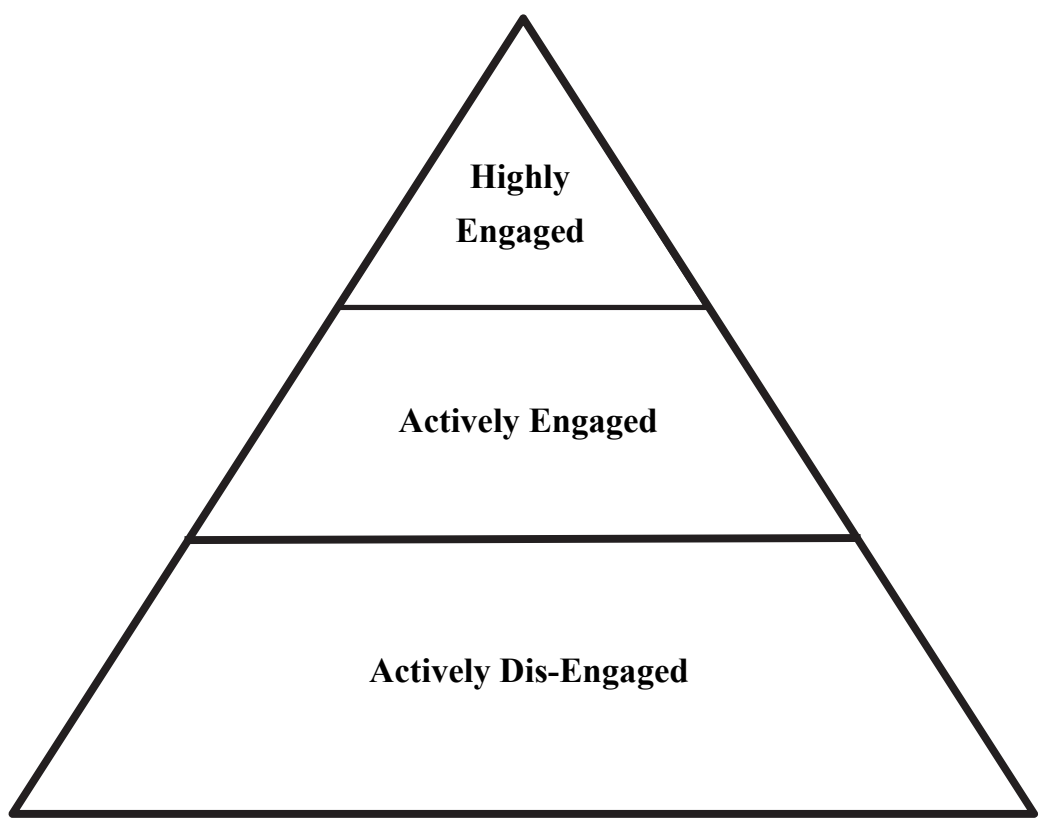

Figure 1. The Pyramid of Engagement

Source: Own, adopted from (Rheem, 2017)

\subsection{Employee Job Satisfaction}

Job satisfaction is a term that is directly related to the employee's engagement level (Markos, 2010). It is highly related to employee engagement as employee satisfaction within the company interprets to higher loyalty and therefore higher productivity and engagement (Soanne, 2008). Job satisfaction is defined to be whether employees are happy and fulfilling their needs desires and at their works. Employee internal satisfaction reflects on several measurements like employee motivation, dedication, and goal achievement (Mete et al., 2016).

Job satisfaction is integration between the internal conscious of the employee and the external surrounding environment and they affect each other vice-versa. Job satisfaction is not absolute, it differs in levels and is always found whether internally or externally (Torraco, 2005). The level of satisfaction can't be controlled neither by the company nor the individual solely, it is an integrated process that has multiple factors, and each factor affects all other factors as well as the final output which is the job satisfaction.

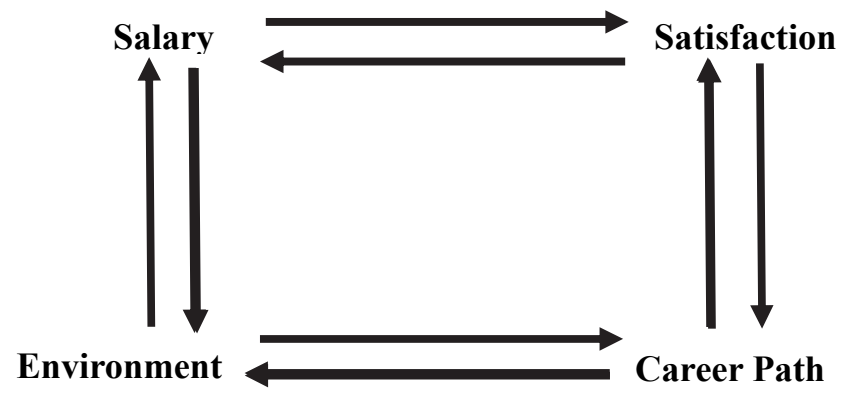

Figure 2. Factors of Engagement

Source: Own, adopted from (Maylett, 2018)

"Work Environment, financial support, policies, employee age, feel of belonging, job security, innovation, flexibility, career progression, promotions, etc..." these are all factors affecting not only the job satisfaction but also each other factor. When discussing the job satisfaction in the context of employee engagement, salary, environment, career path, and job satisfaction are the main four corners of the overall factors illustrated earlier. These four directly related factors affect each other along with the level of engagement (Maylett, 2018). 


\subsection{Antecedents and consequences of employee engagement}

Previous studies have indicated that there are significant differences between the job and the organization engagement, the perceived organizational support could predict both job and organization engagement, while job engagement is determined by tit's characteristics, additionally, the organizational engagement has been predicted by procedural justice (Saks, 2006).

Employee engagement is affected and affecting at the same time. Antecedents like job characteristics, organizational support and recognition are all causes of creating employee engagement, for sure different levels of antecedents cause different levels. Afterward, Employee engagement will lead to job satisfaction vice versa and create higher organizational commitment and less intention to quit. There is a direct "positive and negative" relationship between the causes of employee engagement and the consequences of it as shown in the illustration below (Saks, 2006).

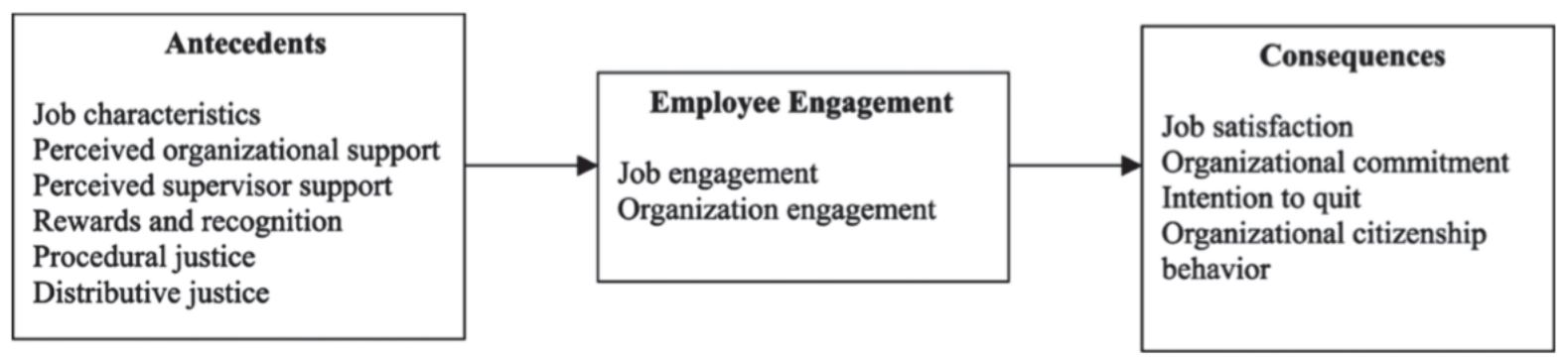

Figure 3. Antecedents \& Consequences of Employee Engagement

Source: (Saks, 2006)

\subsection{Employee Engagement and Organizational Performance}

Investing in employee engagement is so important for companies as employee engagement is significantly related to significant business outcomes. Researches have shown that employee engagement influences organizational performance outcomes like productivity, profitability, employee retention, safety, and customer loyalty. And also, researches have indicated that there is a direct positive relationship between employee engagement and overall company's profitability and competitiveness as it can exceed the average profit growth in the industry (Markos et al., 2010).

Many types of research on employee engagement have indicated that engagement is positively related to customer satisfaction (Ellis and Sorensen, 2007; Coffman, 2000; Hewitt Associates, 2004; Coffman and Gonzalez-Molina, 2002; Towers Perrin Talent Report, 2003; Heintzman and Marson, 2005). The engaged employee consistently demonstrates high performance while interacting with any stakeholder whether internally like peers and management or externally with customers, vendors, and the public.

On the other hand, if employees are disengaged, it is more likely that the company will be losing talent and efforts on tasks that may not matter much, and even if it matters, it will not be as productive and effective as if they were at least engaging. Employees will also show a lack of commitment and participation in reflecting the company's goals. Moreover, some disengaged employees might be splitting which means they won't be considering any change with the company (Perrin Report, 2003; BlessingWhite, 2006). Based on the results of a survey conducted by ISR "Institute for social research" on 360,000 employees from different 41 companies worldwide in the top ten world's economically robust countries; the results find that both net profit margins and operating margin were reduced over a 3 year period with companies with low engagement, whereas these measures will be increased over a specified period in the high level of engagement companies (Meere, 2005).

\subsection{Drivers for Engagement Strategies}

At this point in the research, it is clear that employee engagement is highly important and needs attention and efforts by companies to maintain a steady developed level of engagement. Engagement is highly related to the employee behavior and conscious, therefore employee engagement can't be obtained by specific fixed steps as it might differ from an employee to another. This doesn't mean that there could be a range of useful strategies and efforts that can be implied by the company to positively affect the physical and mental consciousness of the 
employee. The researcher Solomon Markos in 2010 has set six-point tablets that -as he states- should be applied by every company to reduce employee disengagement and benefit from employee's full job potentials:

\subsubsection{Start it on Day One}

Most of the organizations have talented efficient acquisition strategies, but they lack of employee's retention strategies. Orientation programs and effective recruitment are the primary pillars to be placed on the first day of a new employee. Moreover, managers need to be careful in extracting the new employee potential talents through their effective recruitment.

\subsubsection{Start it from the Top}

Employee engagement entails leadership commitment through incorporating clear values, vision, and mission, unless people at the top-level own it, believe in it, push it down to employees, managers, and improve their leadership, employee engagement then will never be more than just a "corporate fad" or "another HR thing".

\subsubsection{Enhancing Employee Engagement Throughout Two-Way Communication}

Managers need to promote two-way communication. Employees are not chess stones moving according to your orders ideas without giving them the chance to express their opinion on main issues that affect their job and life.

\subsubsection{Giving Satisfactory Opportunities for Advancement and Development}

It is crucial to encourage independent thinking among employees through granting them more job autonomy; so, it will give them great chance to get their freedom to choose the best way of doing their job as long as their performance within the intended outcome of the company.

\subsubsection{Ensuring that Employees Have the Required Resources to do Their Jobs}

It is expected from managers to ensure that their employees have access to all the required resources as material, physical or, information and financial resources in order to accomplish the job requirements effectively.

\subsubsection{Giving Employee'S Appropriate Training}

The company should help its employees to update themselves through enhancing their skills and knowledge by giving them the appropriate training. Normally, it is obvious that when your employees seeking to know more about their jobs it will increase their confidence to enable them to work without headache supervision from their direct managers which in turn helps to improve their commitment and self-efficacy (Markos, 2010).

\section{Study Questions}

- What is employee engagement level and how is it measured?

- What are the main factors affecting employee engagement and how do employee perceive it?

- Do employees' level of engagement and commitment enhance the company's competitiveness; if so, how?

- How can companies increase employee engagement level in the Palestinian economy?

\section{Methodology}

\subsection{Research Approach}

This study utilizes a Mixed Research Approach stream because it integrates the quantitative numeric and qualitative descriptive data in parallel. The mixed Approach is due to the research main objectives that are about the employee engagement level and how to improve it in the Palestinian business market. This study provides a qualitative and quantitative analysis of the current understanding and measurement of employee engagement level and the descriptive verbal output of how to improve employee level of engagement from level to another.

The mixed Research Approach is a research in which the researcher collects, analyses, integrates, and generates both quantitative and qualitative results in a single study. (Johnson et al., 2007, cited in Cameron, 2011). This approach is adopted when aiming to obtain a descriptive and new problem solution for a specific phenomenon. The mixed research approach has been becoming increasingly attached to such researches and recognized as the third major research approaches (Johnson, 2007).

\subsection{Research Design}

This study uses Causal study design, collecting live data of the selected sample identified using simple random sampling. The change of specific variables regarding the current affected conditions with other un-affected condition who have not been exposed to these changes. This will be done by collecting data of the 55 -respondent sample through questionnaire addressing and one-to-one interviews, data analyzing took place to clarify the current situation into the studied companies. 
This study design is believed to be relatively flexible with changing conditions across time. It will be very beneficial for future researches related to this topic as it will be possible for them to have a direct comparison and description of the level of success and credibility of the study results and recommendations. This will set the opportunity for future researchers to widen their study horizon and long-term goals.

The authors used the Cross-Tabulation method to perform the data analysis of the study instrument for all its sections.

\subsection{Population and Sampling Method}

The target population of this study is the private and governmental organizations in Palestine which are aligned with the research approach and objectives. The sample chosen from different organizations located in West BankPalestine, 55 respondents participated in this survey. This research used simple random sampling. Furthermore, the sample is a part of the target population which is the private and government sectors.

The questionnaire consists of 5 main parts as the following: (1. General Information, 2. The company, 3. Management, 4. Operations, and 5. Needs).

\section{Results and Discussions}

In this section, authors have explained the main results of this study through the main study questions and the most significant items in the questionnaire which have the greatest impact in the study.

\subsection{Descriptive Analysis (Frequencies)}

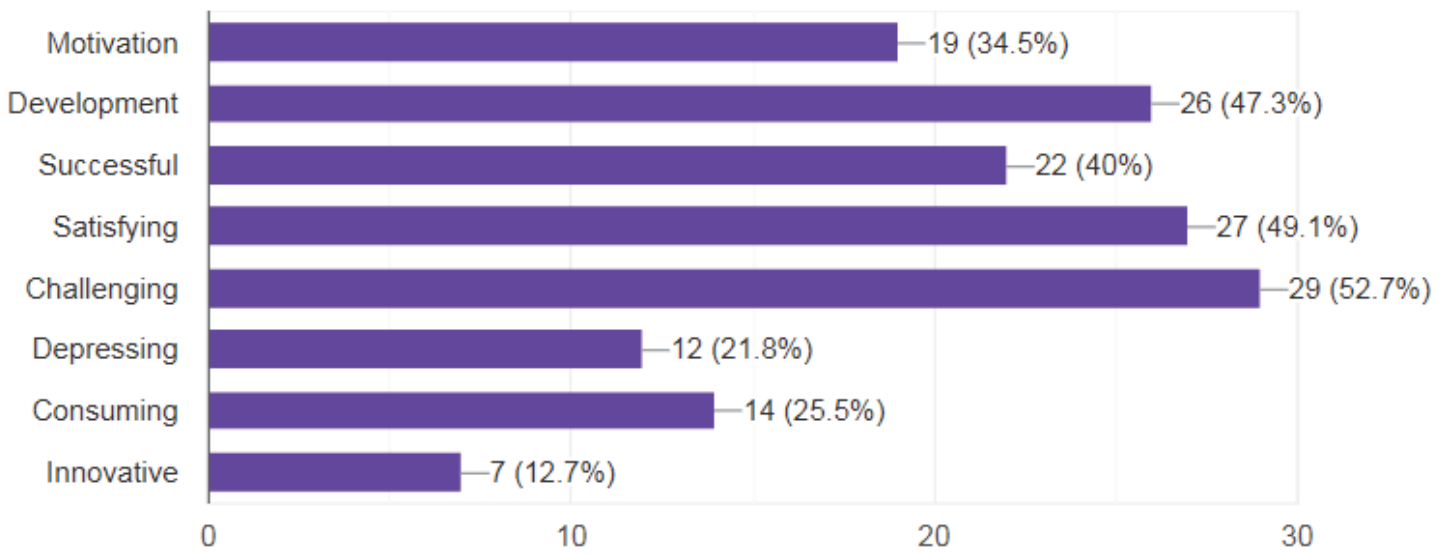

Figure 4. What are the top three words that relate to your job right now?

Source: Own

In figure 4 showed above, the sample has stated the most descriptive words of their jobs, and $52 \%$ stated that they see it challenging, $49 \%$ felt their jobs are satisfying, $47 \%$ stated it's a development job, $40 \%$ felt they are doing a successful job, $34 \%$ felt their jobs are motivating, $25 \%$ felt it's a consuming job, $22 \%$ felt their current jobs are depressing, while only $13 \%$ felt their jobs are innovative. 


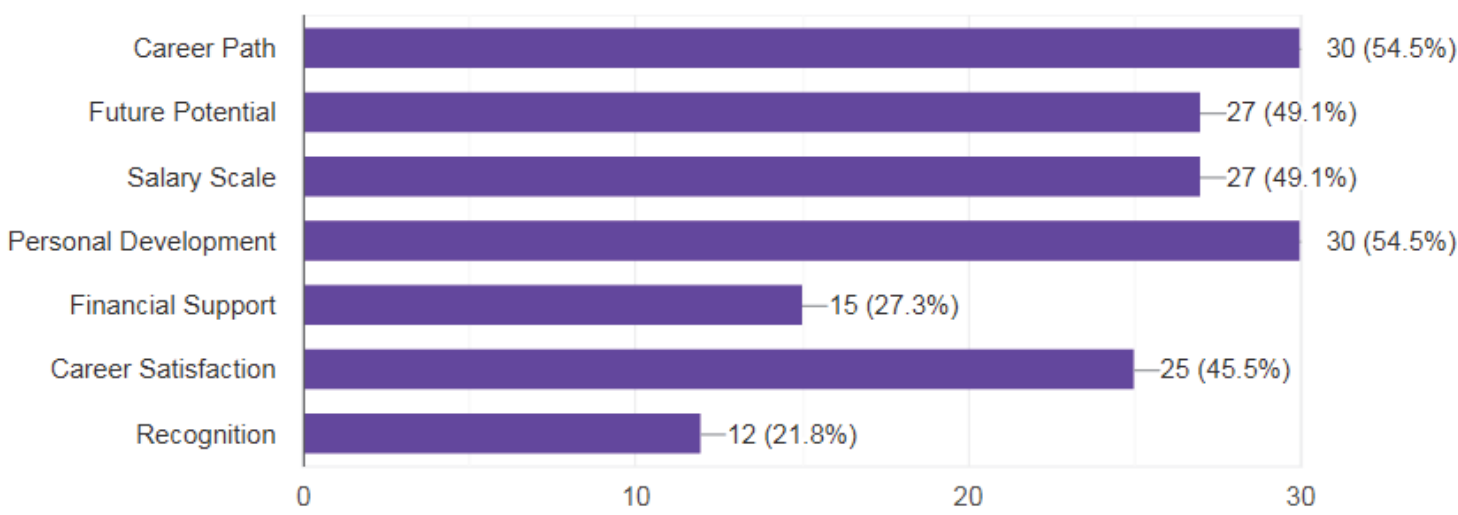

Figure 5. From your personal perspective, what are the most factors affecting your engagement within your company?

Source: Own

As figure 5 shows the factors affecting the employee's engagement in their companies from their own perspective, career path was selected by $54 \%$ of the sample, personal development was selected by $54 \%$ as well, salary scale and future potential were chosen by $49 \%$ of the sample, career satisfaction was selected by $45 \%$, financial support was chosen by $27 \%$ and recognition was chosen by $22 \%$ of the sample.

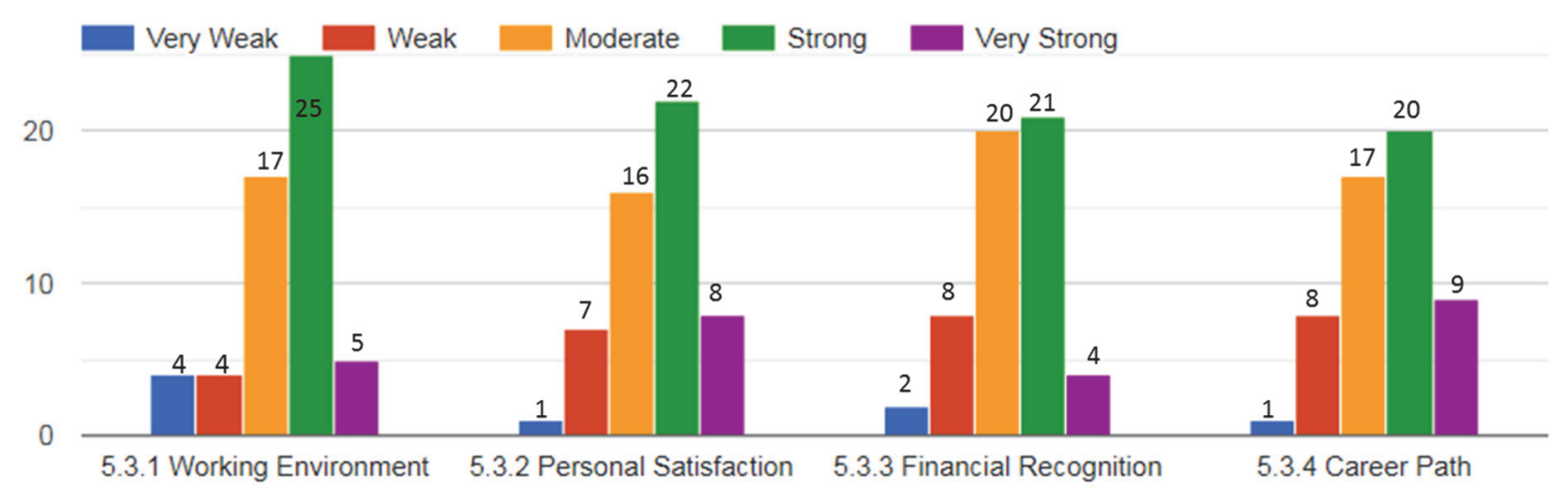

Figure 6. On a scale from 1-5 "one is the lowest", Rank each engagement pillar on how much it affects your personal engagement

Source: Own

Figure 6 shows, the sample weighted each pre-set engagement factor of how much it affects them from very weak to very strong, the sample stated that all the factors (working environment, personal satisfaction, financial recognition, and career path) has a strong effect on their engagement at $(45 \%, 40 \%, 38 \%, 36 \%)$ respectively. ( $30 \%$, $29 \%, 36 \%, 30 \%)$ viewed them all as weak respectively. $(9 \%, 14 \%, 7 \%, 16 \%)$ viewed them as very strong factors respectively. $(7 \%, 12 \%, 14 \%, 14 \%)$ viewed them all as weak factors respectively. $(7 \%, 1 \%, 3 \%, 1 \%)$ viewed them all as very weak factors respectively.

\subsection{Descriptive Analysis (Cross Tabulation)}

Table 1. Tasks Acknowledgment VS How long they have been in the company

\begin{tabular}{ll}
\hline Tasks Acknowledgment VS How long they have been in the company & Rate $\%$ \\
\hline $2-5$ years & $16 \%$ \\
\hline
\end{tabular}




\begin{tabular}{ll}
\hline Agree & $58 \%$ \\
Strongly Agree & $42 \%$ \\
\hline 6-8 years & $5 \%$ \\
\hline Agree & $100 \%$ \\
\hline Less than 2 years & $49 \%$ \\
\hline Agree & $30 \%$ \\
Can't Decide & $38 \%$ \\
Disagree & $16 \%$ \\
Strongly Agree & $16 \%$ \\
\hline More than 8 years & $30 \%$ \\
\hline Agree & $38 \%$ \\
Disagree & $19 \%$ \\
Strongly Agree & $43 \%$ \\
\hline Grand Total & $100 \%$ \\
\hline
\end{tabular}

Source: Own

From the cross-tabulation table above (Tasks Acknowledgment VS How long they have been in the company) it shows that all employees who have been in the company between 2-5 years well acknowledging their tasks with $58 \%$ agree and $42 \%$ strongly agree. While all employees who have been in the company for more than five years well acknowledge their tasks. And $81 \%$ of the people who have been in the company for longer than 8 years well acknowledge their tasks while $19 \%$ only disagree. Finally, $49 \%$ of employees who have been in the company for less than 2 years well acknowledge their tasks while 16\% don't and 38\% couldn't decide whether to agree or not.

Table 2. Level of Employment VS I have a career path in this industry

\begin{tabular}{ll}
\hline Level of Employment VS I have a career path in this industry & Rate \% \\
\hline First level jobs & 45.5 \\
\hline Agree & 34 \\
Can't Decide & 15 \\
Disagree & 38 \\
Strongly Agree & 6 \\
Strongly Disagree & 7 \\
\hline Middle Management & 40 \\
\hline Agree & 32 \\
Can't Decide & 18 \\
Disagree & 13 \\
Strongly Agree & 28 \\
Strongly Disagree & 9 \\
\hline Senior Management & 14.5 \\
\hline Agree & 38 \\
Disagree & 15 \\
Strongly Agree & 28 \\
Strongly Disagree & 19 \\
\hline Grand Total & $100 \%$ \\
\hline
\end{tabular}

Source: Own

From the above table (Level of Employment VS I have a career path in this industry), it is shown that $40 \%$ of employees at the first level employment feel that they have a clear career path in the same company with $34 \%$ 
agree and $6 \%$ strongly agree. While $45 \%$ felt that they don't have a clear career path with $38 \%$ disagree and $7 \%$ strongly disagree, and $15 \%$ felt neutral. While $60 \%$ of employees at middle level employment felt they have a clear career path in the company with (32\% agree and $28 \%$ strongly agree, $22 \%$ stated that they don't feel they have clear career path with (13\% disagree and $9 \%$ strongly disagree), $18 \%$ couldn't decide whether they agree or not to this statement. Finally, $65 \%$ of employees agreed that they have clear career path within the company since they are in the senior level management with (38\% agree and $28 \%$ strongly agree), while $34 \%$ disagreed with the statement from the same level of employment with (19\% strongly disagreed and $15 \%$ disagreed). $0 \%$ of the senior level managers felt neutral since they are at the senior level and clearly state their feeling towards this statement.

Table 3. Ownership of the company VS Rarely Looking for another job

\begin{tabular}{ll}
\hline Ownership of the company VS Rarely Looking for another job & Rate\% \\
\hline Governmental & 58.1 \\
\hline Agree & 19 \\
Can't Decide & 11 \\
Disagree & 26 \\
Strongly Agree & 6 \\
Strongly Disagree & 38 \\
\hline Private & 43.6 \\
\hline Agree & 32 \\
Can't Decide & 13 \\
Disagree & 9 \\
Strongly Agree & 24 \\
Strongly Disagree & 22 \\
\hline Grand Total & $100 \%$ \\
\hline
\end{tabular}

Source: Own

As the cross-tabulation table above (Ownership of the company VS Rarely Looking for Another Job) shows, 25\% of the governmental sector rarely look for another job with (19\% agree and $6 \%$ strongly agree) and $64 \%$ do look for other jobs when possible with (38\% strongly disagree and $26 \%$ disagree), $11 \%$ couldn't decide. While $56 \%$ of the private sector employees agreed that they rarely look for other jobs with (32\% agree and $24 \%$ strongly agree), $31 \%$ disagreed with the statement with ( $9 \%$ disagree and $22 \%$ strongly disagree), and $13 \%$ felt neutral and couldn't decide whether yes or no.

\subsection{Answers of Study Questions}

\section{Research Question (1): What is employee engagement level and how is it measured?}

It was clear from the beginning of the literature review that employee engagement has various different definitions based on different perspectives, eventually we chose to adopt one definition adopted Kahn's definition "the harnessing of organization members' selves to their work roles, in engagement, people employ and express themselves physically, cognitively, and emotionally during their performances" (Kahn, 1990) as it integrates most of the other definitions on a way or another, and it analyses the relationship between employee engagement level and company's internal stakeholders that upon Kahn's effect the performance of the employee eventually.

\section{Research Question (2): What are the factors affecting employee engagement and how do employee perceive it?}

When researching the employee engagement factors, we approached some HR officers at the study sample for a one-to-one interview with a human resource expert employee at one of the Palestinian ministries associated with finance as $58.1 \%$ of this sample was from the governmental sector, the HR officer clearly stated that employee engagement is directly related to the internal environment of the entity as it is day-to-day process the employees get exposed to the in the internal human power related policies. Mr .X stated that the motivation factors like financial efforts, sharing the vision of the company, creating communication with employees from different 
departments and in different levels within the same department, in addition to discussing the external entity related stimulus from outside factors among employees. All these factors are directly affecting the employee's engagement based on Khan's definition we adopted earlier as Mr. X agreed on.

\section{Research Question (3): Do employees' level of engagement and commitment enhance the company's competitiveness if so, how?}

When researching the relation between the employee engagement level and the company's competitiveness. The engagement was directly related to the company's competitiveness as the company competitiveness is based not only on the financial profit but also in the internal stakeholders and the main key success factor which is the human power commitment. When $54 \%$ of employees agreed that they feel well affiliated to the company's vision, $47 \%$ agreed that they will recognize staying at their same company for the next 3 years' career time, and $52 \%$ agreed that they feel the company motivates them to go beyond their potential. These numbers show that higher engagement among employees pushes them not only to stay longer in their current companies but to give more than full potential. It is undeniable that when employees perform better by self-motivation or any other motivating factors that create employee satisfaction the company overall performance of the company will be improved with more efficient productivity and higher employee loyalty outside the working hours which gives the companies a differentiating step-ahead benefit in the industry regarding any other company in the same industry.

\section{Research Question (4): How can companies increase employee engagement level in the Palestinian economy?}

When discussing the engagement level with respect to the Palestinian economy with Mr. X, he stated that financial satisfaction is a necessity for any employee as it goes along with the overall economic structure of the Palestinian economy where individuals are financially oriented with their financial commitments and basic life needs affording that goes higher day by day. Mr. X stated that financial satisfaction offers the company a full concentration on the jobs tasks completion as employees won't be disturbed with looking for extra financial alternatives outside their current positions. This goes along the quantitative results we analyzed as financial satisfaction factor was chosen by $38 \%$ of the sample as a crucial factor. The working environment was also pointed out by Mr. X as he said the social structure in the Palestinian culture highly depends on the word-of-mouth power as people discuss any issues outside their companies whether it's true fact or a rumor. Which means that a good working environment will lead to a positive public reputation generated by the employees themselves whether by reflecting the company's positive environment or defending the negative external rumors. This also goes along with the quantitative result we got when the sample chose the working environment as the number one strongest factor by $45 \%$ of the sample responses.

\section{Conclusion}

Employee engagement level was a term to be defined at the beginning of this research, employee's importance and human power optimization were and approved to be the key success factor for any company. The main resource of any company was started from the beginning of the study to be Human Power. Like any other resource, we always tend to get the best possible output from different variables associated with the study. In the case of the human resource, we did not look at it only as a resource to benefit from but also a resource to invest in for the future of the nations before the businesses.

Our study started by collecting secondary information about the employee engagement level and how to improve it through previous related studies. Studies about this topic in the Palestinian industry were not that much but that doesn't mean there were not any simple theories and economic basis to start from. We adopted one clear definition of employee engagement and built our research upon its pillars and perspectives.

The study shows that employees need to be recognized both as an asset and as a customer at the same time. An asset when it comes to maintaining the asset operating with $100 \%$ power and potential, and with loyalty and satisfaction creation when it comes to the customer side. All business activities become part of the employee lifestyle in some way or another, some actions might affect the employee directly, and some others will be indirect. The common factor here is that they will be affected eventually. So, the key here is to control these effects in order to control the reaction generated by the employees that might be for example a low employee engagement like disengaging.

Importance of the engagement has been clarified previously with examples and numbers. The internal and external factors affecting the engagement level has been mentioned as well to lead on how to motivate these factors after all. It is very important to understand that employee engagement is not only affected by the financial part of the business. Higher salaries do not mean higher loyalty and high voluntary engagement level; neither low salary has a low engagement level. 
It was obvious when going through the literature review that studies regarding this topic have been international and not regarding the Palestinian market in specific. There have been no specific studies regarding this topic into Palestine, that's why this study is important to recognize as it will be the corner-stone for future Human Capital development with respect to the Palestinian market conditions. Using up-to-date information and results from the local market itself.

The Human Power is the most important resource to invest in for any nation, starting from educating children and ending with the future careers and incubation in the future building of their nations. The human mental and physical power should not end and be consumed in the career life but employees should believe in their responsibility and contribution not only on filling their positions but also in leading this nation and country to strong independent economic and authority independence. To but Palestine in the map of development and to brighten the future not only to our children but to our beloved Palestine.

\section{Limitations \& Recommendations}

\subsection{Limitations}

The main challenge for authors in this study which is many companies in Palestine do not have good employee engagement programs to get the real practical image for employee engagement role models. Additionally, reaching the specialists and HR experts wasn't that easy task, sharing such information in this regard is somehow difficult for them, which it restrains to obtain more information and practical examples.

\subsection{Recommendations}

The authors have generated a specific recommendation for the professionals and HR experts and everyone interested or working in this field whether officers or top managers, the recommendations are divided into three main parts as follows:

\subsubsection{Deeper Studies in this Field in Specific}

Through this study, it was clear that employee engagement level is a crucial hot topic among all types of organizations from different sizes and industries. Even when companies did not recognize this issue, they draw high attention on this topic when we approached as we opened their eyes to a broad new horizon.

The study did cover the basic employee engagement definition and strategies to transfer employees from the lowest engagement level to the highest. However, it did not cover $100 \%$ of the case, neither from the overall possible strategies or all factors or stimulus. Therefore, authors recommend having a deeper more specific studies in this topic and the related fields like "Recruitment, Capacity Building, Employee Satisfaction" as these topics are related to the level of employee engagement some way or another.

\subsubsection{Adopting the Employee Engagement Transforming Strategies by the Public Sector Before the Private One}

Employee engagement level was proven to be directly related to the efficiency of work and the overall company performance. When talking about the private sector it is mainly profit-oriented and having a vision for a stronger business, which is not bad as it is the private sector and always has good side effects on the overall economic performance of the country. But when talking about the Public sector organization, having strong strategies for improving the Employee Engagement will be directly affecting the governmental organizations' performance starting from its employees. Long-term career and job security are all guaranteed in the governmental sector in Palestine as the government stays away from expelling employees unless for serious rare issues. Which means employees are feeling safe from the security perspective, and not looking for other main jobs rather than their current ones. Having this combination is a key success for the governmental institutions to have the maximum potential of their employees for the longest possible time through improving their working environment and having a high engagement level in and out of work.

The effect of governmental institutions performance is more visible than the private sector as it is directly into the nation's overall operations and performance. The government is the number one employer in Palestine with over than 160 thousand employees in the West Bank only based on the Palestinian Central Bureau of Statistics report in the fourth quarter of the year 2018. The effect of engaging these 160 thousand employees will have a massive push to the economy not only behind their disk productivity but also in their daily life activities.

7.2.3 Businesses Must Have Engagement Transforming Strategies That are Employee-Oriented and Not EntityOriented

Going through the research, it was obvious from the businesses that their main objective when looking to employee's productivity and engagement is only to increase their numeric profits in the first place. Which is not a bad intention, but at the end of the day, employee engagement strategies should be centralized upon employees 
themselves and not the company at the first place. The company will always be benefited when having a high employee engagement but they should aim not only for the numeric profits, these strategies will lead to but also to the strong good reputation and their intangible credit they will have in the industry which is not measured by numbers, but absolutely lead to positive business performance, higher stock price, and at the end of the day a good numeric output.

\section{References}

Alan M. S. (2006). Antecedents and consequences of employee engagement. Canada. https://doi.org/10.1108/02683940610690169

Arthur, J. B. (1992). The link between business strategy and industrial relations systems in American steel minimills. Industrial and Labor Relations Review, 45, 488-506. https://doi.org/10.1177/001979399204500306

Bailey, T. (1993). Discretionary effort and the organization of work: Employee participation and work reform since Hawthorne. Working paper, Columbia University, New York.

Baumruk, R. (2004). The missing link: the role of employee engagement in business success. Workspan, 47, 4852.

Blessing, W. (2006). Employee Engagement Report 2006 BlessingWhite, Inc. Princeton, New Jersey. Retrieved May 29, 2019, from www.blessingwhite.com

Cameron R. (20111). Mixed Methods Research: The Five Ps Framework. The Electronic Journal of Business Research Methods, 9(2), 96-108.

Coffman C. (2000). Is Your Company Bleeding Talent? How to become a true "employer of choice". The Gallup Management Journal. The Gallup Organization, Princeton, NJ.

Coffman, C., \& Gonzalez-Molina, G. (2002). Follow this Path: How the world's greatest organizations drive growth by unleashing human potential. New York Warner Books, Inc.

Ellis C. M., \& Sorensen A. (2007). Assessing Employee Engagement. The Key to Improving Productivity.

Frank, F. D., Finnegan, R. P., \& Taylor, C. R. (2004). The race for talent: retaining and engaging workers in the 21 st century. Human Resource Planning, 27(3), 12-25.

Freud, S. (1922). Employee engagement: Does it exist, and if so, how does it relate to performance, other constructs and individual differences? Retrieved March 9, 2019, from http://www.lifethatworks.com/Employee-Engagement.prn.pdf

Heintzman R., \& Marson B. (2005). People, service and trust: Links in a public sector service value chain. Hewitt associates LLC. https://doi.org/10.1177/0020852305059599

Hewitt. (2004). Employee engagement higher at double digit growth companies. Research Brief. International Review of Administrative Studies, 7(4), 549-575.

Johnson, R. B., Onwuegbuzie, A. J., \& Turner, L. A. (2007). Toward a Definition of Mixed Methods Research. Journal of Mixed Methods Research, 1(2), 112-133. https://doi.org/10.1177/1558689806298224

Kahn, W. A. (1990). Psychological conditions of personal engagement and disengagement at work. Academy of Management Journal, 33, 692-724. https://doi.org/10.5465/256287

Markos, S., \& Sridevi, S. (2010). Employee Engagement: The Key to Improving Performance, India. The Five Keys of Employee Engagement. Retrieved May 29, 2019, from https://decision-wise.com/the-five-keys-ofemployee-engagement/

Meere, M. (2005). High cost of disengaged employees Victoria: Swinburne University of Technology. Retrieved May 29, 2019, from http://www.swinburne.edu.au/corporate/industrysolutions/ee/reports/Employee\%20Engagement\%20in dustry\%20Breifing\%20Paper\%20Dec\%202005\%20.pdf

Mete, E., Sökmen, A., \& Biyik, Y. (2016). The Relationship between Organizational Commitment, Organizational Identification, Person-Organization Fit and Job Satisfaction: A Research on IT Employees. International Review of Management and Business Research, 5(3). Retrieved May 29, 2019, from http://www.irmbrjournal.com/papers/1468417366.pdf

Perrin T. (2003). Working Today: Understanding What Drives Employee Engagement The 2003 Towers Perrin Talent Report U.S Report. Retrieved from http://www.towersperrin.com/tp/getwebcachedoc? Webc $=$ HRS 
/USA/2003/200309/Talent_2003.pdf

Perrin T. (2003). Working Today: Understanding What Drives Employee Engagement The 2003 Towers Perrin Talent Report U.S Report. Perspectives, 15(1). The Segal Group, Inc. Retrieved May 29, 2019, from http://www.towersperrin.com/tp/getwebcachedoc? Webc = HRS /USA/2003/200309/Talent_2003.pdf

Ramus, C. A. (2001). Organizational support for employees: encouraging creative ideas for environmental sustainability. California Management Review, 43(3), 85-105. https://doi.org/10.2307/41166090

Rheem, D. (2017). Thrive by design: The neuroscience that drives high-performance cultures. Charleston, SC: ForbesBooks.

Saks, A. M. (2006). Antecedents and consequences of employee engagement. Journal of Managerial Psychology, 21(7), 600-619. https://doi.org/10.1108/02683940610690169

Sandeep, K., Mark, G., Chris, R., Emma, S., \& Katie, T. (2008). Employee Engagement: A Literature Review. Kingston.

Torraco, R. J. (2005). Work design theory: A review and critique with implications for human resource development. Human Resource Development Quarterly, 16(1), 85-109. https://doi.org/10.1002/hrdq.1125

Truss, C., Soane, E., Edwards, C., Wisdom, K., Croll, A., \& Burnett, J. (2006). Working Life: Employee Attitudes and Engagement. London, CIPD.

\section{Copyrights}

Copyright for this article is retained by the author(s), with first publication rights granted to the journal.

This is an open-access article distributed under the terms and conditions of the Creative Commons Attribution license (http://creativecommons.org/licenses/by/4.0/). 